\title{
Application of Low Cost Natural Rubber Films for Water Remediation
}

\author{
Nurul Hasliza Hasanuddin, Tan Yee Chien, Asmaa' Zainal Abidin, \\ Noor Hana Hanif Abu Bakar* and Tan Wei Leng \\ School of Chemical Sciences, Universiti Sains Malaysia, \\ 11800 USM Pulau Pinang, Malaysia \\ *Corresponding author: hana_hanif@usm.my
}

Published online: 15 November 2017

To cite this article: Hasanuddin, N. H. et al. (2017). Application of low cost natural rubber films for water remediation. J. Phys. Sci., 28(3), 81-94, https://doi.org/10.21315/ jps2017.28.3.6

To link to this article: https://doi.org/10.21315/jps2017.28.3.6

\begin{abstract}
Pristine natural rubber (NR) and its composites including natural rubberhalloysite nanotube (NR-HNT) as well as natural rubber-silver (NR-Ag) have been prepared in the form of films for the decolorisation of dyes via adsorption as well as degradation. As an adsorbent, the flatsheet NR film was capable in adsorbing methylene blue (MB). However, incorporation of HNT into the films enhanced this property. It was found that the percentage of MB removal increased from $66 \%$ to $93 \%$ within $2 \mathrm{~h}$ when $10 \mathrm{wt} \%$ and $70 \mathrm{wt} \%$ HNT were incorporated respectively. The NR film was also able to function as a catalytic film in the presence of Ag. The flatsheet $\mathrm{NR}-\mathrm{Ag}$ films degraded $\mathrm{MB}$ with $\mathrm{Ag}$ content of as low as $0.002 \mathrm{wt} \%$. Furthermore, we show that the efficiency of these films can be improved by preparing porous NR films. This work shows how the function of NR can be altered by incorporating various fillers.
\end{abstract}

Keywords: Natural rubber, halloysite nanotubes, silver, degradation, adsorption

\section{INTRODUCTION}

Urbanisation has resulted in the use of a wide range of cationic dyes in numerous industries such as textiles, pulp mills, leather, dye synthesis, printing, plastic and food. This has led to water pollution, which results in malicious odours and unpleasant views. Indirectly, the quality of water drastically decreases and harms aquatic life. There exist several methods to treat the coloured contaminant effluent from industrial area. Adsorption using adsorbents such as $\alpha$-chitin nanoparticles, activated carbon, chitosan, kaolin and rubber from waste tires is one of the 
methods which show potential for removal of dyes. ${ }^{1-5}$ Catalytic degradation using catalysts such as $\mathrm{Ag}, \mathrm{TiO}_{2}$ and $\mathrm{ZnO}$ is another method frequently employed. ${ }^{6-9}$ Although numerous works employing either of the methods are available, the use of NR which consists of repeating cis-1,4-polyisoprene units for these purposes, have not been fully exploited.

Natural rubber is an inexpensive environmental friendly polymer which is readily available throughout Southeast Asia. To date, this polymer, which is in the form of composites, has shown great potential to be used for water remediation purposes. ${ }^{10}$ As examples, previous works have reported the adsorption of MB on NR/Chitosan blends as well as the adsorption of direct violet dye onto natural rubber chips. ${ }^{11,12}$ In addition, researchers have also reported the use of NR composites as catalyst. In recent work, $\mathrm{NR} / \mathrm{TiO}_{2}$ and $\mathrm{NR} / \mathrm{TiO}_{2} \mathrm{Ag}$ were used as photocatalysts for dye degradation. ${ }^{13,14}$ In the work reported by Stropa and coworkers, the presence of Ag did not show a significant impact on the degradation of MB. ${ }^{14}$ Other researchers have also used activated carbon (AC) and $\mathrm{TiO}_{2}$ with $\mathrm{NR}$ to degrade the same dye under UV light exposure. ${ }^{15}$

To our knowledge, no work has discussed in detail the potential of NR composites containing halloysite nanotubes (HNT) or solely Ag for the decolorisation of dyes. Hence, in this work, we demonstrate how NR can act as an adsorbent and how its capability and function can be altered by modifying it with various fillers such as HNT and Ag nanoparticles. It has been shown that HNT can be used as an adsorbent for adsorption of MB. However, its disadvantage is that the wastewater has to go through sedimentation process to obtain a clear treated solution. ${ }^{16}$ Immobilising HNT on NR may be the answer to this dilemma. Subsequently, Ag has also been exploited as a catalyst. Hence incorporation of this noble metal on NR can result in a film that can decolorise dyes via adsorption and degradation.

\section{EXPERIMENTAL}

\subsection{Materials}

All chemicals were used as received. Natural rubber latex (60\% dry rubber content) was obtained from Malaysian Rubber Board, Kuala Lumpur as a gift. HNT was purchased from Sigma-Aldrich, $\mathrm{AgNO}_{3}$ and $\mathrm{MB}$ from $\mathrm{R} \& \mathrm{M}$ Chemicals while sodium dodecyl sulfate (SDS) (99\%) from Acros Organics Belgium. 


\subsection{Fabrication of Flatsheet NR Films}

\subsubsection{Preparation of NR films via latex casting (NR)}

As much as $1 \mathrm{~g}$ of natural rubber latex (NRL) was dispersed in a mould. The latex was then dried for $5 \mathrm{~h}$ in an oven at $50^{\circ} \mathrm{C}$ and used directly for adsorption studies.

\subsubsection{Preparation of NR-HNT films}

Typically, the $10 \mathrm{wt} \%$ NR-HNT film was prepared by homogenising $1.6 \mathrm{~g}$ of NRL with $0.1 \mathrm{~g}$ of HNT dispersed in $2 \mathrm{ml}$ of SDS. After stirring for $2 \mathrm{~h}$, the mixture was cast and dried in an oven at $45^{\circ} \mathrm{C}$. Similar procedures were employed for the preparation of NR-HNT films with 30, 50 and $70 \mathrm{wt} \%$ of HNT, however, the amount of HNT was varied. The pristine NR film was prepared by mixing $1.6 \mathrm{~g}$ of NRL with $2 \mathrm{ml}$ of distilled water.

\subsubsection{Preparation of NR-Ag films}

An amount of $1 \mathrm{~g}$ of latex was cast in a beaker. It was then left to dry before adding $55.6 \mu 1$ of $1 \times 10^{-4} \mathrm{M} \mathrm{AgNO}_{3}$ solution. The NR-Ag film was then dried in an oven for $5 \mathrm{~h}$ with a temperature of $50^{\circ} \mathrm{C}$. The wt $\%$ of Ag tested were varied at $3.0 \times 10^{-4}$, $7.0 \times 10^{-4}, 11.0 \times 10^{-4}, 18.0 \times 10^{-4}$ and $20.0 \times 10^{-4} \mathrm{wt} \%$.

\subsection{Fabrication of Films for Comparison Studies}

\subsubsection{NR-Ag porous films}

The NRL was air dried to form dry rubber. As much as $1.0 \mathrm{~g}$ of the dry rubber was cut into small pieces and dissolved in $40 \mathrm{ml}$ of chloroform. The mixture was mixed with $10 \mathrm{ml}$ DMF solvent and stirred for $3 \mathrm{~h}$ to obtain a homogeneous and clear solution. The solution was heated at $38^{\circ} \mathrm{C}$ for $30 \mathrm{~min}$ before electrospining using an Esprayer ${ }^{\mathrm{TM}} \mathrm{ES}-2000$. The temperature of the chamber was kept at $28^{\circ} \mathrm{C}$ to $32^{\circ} \mathrm{C}$ and was monitored using the Esprayer Multi 1.1 software. A voltage of $18 \mathrm{kV}$ was applied to the sample with an extrusion rate of $15 \mu \mathrm{min}^{-1}$. The prepared solution was placed in a syringe having a needle with an internal diameter of $0.5 \mathrm{~mm}$. Aluminium foil was placed on the metal collector covered with a non-conductive plastic. The product was collected at a distance of $20 \mathrm{~cm}$ to the syringe tip. The mass of the final porous NR film was approximately $0.13 \mathrm{~g}$.

An amount of $7.4 \mu \mathrm{l}$ of $1.0 \times 10^{-4} \mathrm{M} \mathrm{AgNO}_{3}$ stock solution was dropped onto the prepared NR porous film and $3 \mathrm{ml}$ distilled water was poured to the film in order to homogenise the $\mathrm{Ag}$ metal. Then, the film was dried for $5 \mathrm{~h}$ in an oven at $50^{\circ} \mathrm{C}$. 


\subsubsection{Flatsheet NR-Ag films}

An amount of $0.13 \mathrm{~g}$ of NRL was placed in a mould and was left to dry at room temperature before $7.4 \mu \mathrm{l}$ of $1.0 \times 10^{-4} \mathrm{M} \mathrm{AgNO}_{3}$ stock solution was pipetted onto the NR with $3 \mathrm{ml}$ of distilled water. Then, the film was dried in an oven at $50^{\circ} \mathrm{C}$ for $5 \mathrm{~h}$.

\subsection{Characterisation Techniques}

SEM (Quanta FEG 650) was used to study the morphology of the NR flatsheet and porous films. A small area was cut out from the fabricated films. The samples were mounted on aluminium stubs and sputter-coated (Quorum, Q150TS) with a layer of gold. A voltage of $15 \mathrm{kV}$ was applied and different magnifications were used (200X, 2000X, 10000X) to view the sample.

Flame-AAS from Perkin Elmer (US), AAnalyst 100 was used to analyse the Ag element. Typically, the NR-Ag films were calcined at $500^{\circ} \mathrm{C}$ for $4 \mathrm{~h}$. The obtained dry ashes were then digested using a mixture of $\mathrm{HCl}: \mathrm{HNO}_{3}$ with a ratio of $3: 1$ while heating. The resulting mixture was then diluted with distilled water, filtered and topped up to $25 \mathrm{ml}$ before analysing. The determination of Ag content involved the flatsheet.

\subsection{Adsorption Studies}

MB was employed to investigate the adsorption capability of the NR and NR-HNT films. The effect of HNT weight percentage (wt \%) and initial MB concentration were studied. As much as $10 \mathrm{ml}$ of the MB solution was placed in a sample vial in the presence of a piece of a film. It was then stirred continuously throughout the experiment. The UV-Vis spectra of MB were recorded at predetermined intervals of time to monitor the extent of MB adsorption. The amount of MB absorbed at a certain time was calculated using Equation 1, where $q_{t}$ is the amount of absorbed dye at any time ( $\left.\mathrm{mg} \mathrm{g}^{-1}\right), V$ is the volume of MB solution (1), $C_{0}$ and $C_{t}$ are the initial concentration and concentration of $\mathrm{MB}$ at a certain time $\left(\mathrm{mg} \mathrm{l}^{-1}\right)$, respectively and $W$ is the mass of HNT employed $(\mathrm{g})$ :

$$
q_{t}=\frac{V\left(C_{0}-C_{t}\right)}{W}
$$

\subsection{Catalytic Degradation Studies}

An amount of $20 \mathrm{ml}$ of $6.4 \mathrm{mg} \mathrm{l}^{-1} \mathrm{MB}$ solution was added to the NR-Ag film. Subsequently, $0.027 \mathrm{~g} \mathrm{KBH}_{4}$ in $20 \mathrm{ml}$ distilled water was added as a reducing 
agent. The mixture was homogenised and recorded at predetermined interval of times using a UV-Vis spectrophotometer. The kinetics of MB degradation was calculated based on the first-order reaction model as in Equation 2. The integrated rate law of a first-order reaction is as follows:

$$
\ln [\mathrm{A}]_{\mathrm{t}}=-\mathrm{kt}+\ln [\mathrm{A}]_{0}
$$

where $[\mathrm{A}]_{0}$ is initial concentration of $\mathrm{MB},[\mathrm{A}]_{\mathrm{t}}$ is the concentration of $\mathrm{MB}$ at time $\mathrm{t}, \mathrm{k}$ is the rate constant, and $\mathrm{t}$ is the elapsed time.

\section{RESULTS AND DISCUSSION}

\subsection{NR Films}

The role of NR film as an adsorbent for $\mathrm{MB}$ was investigated using different concentrations of MB dye. From Table 1, it can be seen that the adsorption capacity equilibrium $\left(\mathrm{q}_{\mathrm{e}}\right)$ increased from $0.07-0.31 \mathrm{mg} \mathrm{g}_{\mathrm{HNT}}{ }^{-1}$ when the MB concentrations were increased from 3.2-16 $\mathrm{mg}^{-1}$. Subsequently, the percentage of MB removal increased from $67.5 \%$ to $79.2 \%$ when the $\mathrm{MB}$ concentration was increased from 3.2 to $6.4 \mathrm{mg}^{-1}$ respectively. In contrast, increasing the concentrations of MB to 12.8 and $16 \mathrm{mg} \mathrm{l}^{-1}$ resulted in a decrease in the removal percentage to $64.2 \%$ and $59.3 \%$. As can be seen, optimum adsorption of MB was at a concentration of 6.4 $\operatorname{mg} 1^{-1}$.

Percentage of dye removal is highly dependent on the concentration of the dye. ${ }^{17}$ The trend observed can be best explained by the fact that at lower concentrations of $\mathrm{MB}$, the ratio of adsorption sites to the total dye molecules in the solution is high. Hence, there is a high availability of adsorption sites for the MB molecules to be adsorbed onto the NR surface. ${ }^{18}$ As the concentration of the MB increases, the number of adsorption sites is insufficient to accommodate MB dye molecules. ${ }^{18}$ This can be best explained by the fact that the surface of NR has a limited number of adsorption sites and it becomes saturated upon achieving a certain $\mathrm{MB}$ concentration. ${ }^{19}$ The saturated surface of NR shields the excess of MB molecules from adsorbing onto the adsorption sites of NR surface. This decreases the percentage of MB removal. The data was fitted to the Langmuir, Freundlich and Tempkin isotherm models. This is presented in Figure 1. The Tempkin model best fit the data giving an $\mathrm{R}^{2}$ value of 0.9754 . Values are tabulated in Table 2. 


\subsection{Natural Rubber Composite Films}

\subsubsection{NR-HNT composites}

In a separate work, the potential of flatsheet NR-HNT films as an adsorbent for $\mathrm{MB}$ was investigated and compared to that of pristine NR under similar conditions. In this case, the HNT was sterically stabilised by the NR polymer. The extent in which the dye was adsorbed as a function of HNT content was studied. The amount of absorbed dyes $\left(q_{e}\right)$ and the percentage of MB removal (\%R) of films with different $\mathrm{wt} \%$ of HNT are tabulated in Table 1.

Table 1: Adsorption capacity, $\mathrm{q}_{\mathrm{e}}\left(\mathrm{mg} \mathrm{g}_{\mathrm{HNT}^{-1}}\right)$ of NR and NR-HNT adsorbents.

\begin{tabular}{|c|c|c|c|}
\hline Samples & Concentration $\left(\mathrm{mg} \mathrm{l}^{-1}\right)$ & $\mathrm{q}_{\mathrm{e}}\left(\mathrm{mg} \mathrm{g}_{\mathrm{HNT}^{-1}}\right)^{-1}$ & $\% \mathrm{R}$ \\
\hline \multirow{4}{*}{ NR } & 3.2 & 0.07 & 67.50 \\
\hline & 6.4 & 0.15 & 79.22 \\
\hline & 12.8 & 0.26 & 64.20 \\
\hline & 16 & 0.31 & 59.30 \\
\hline NR & \multirow{5}{*}{5.92} & 1.44 & 51.52 \\
\hline $10 \%$ NR-HNT & & 2.69 & 97.50 \\
\hline $30 \%$ NR-HNT & & 0.64 & 83.90 \\
\hline $50 \%$ NR-HNT & & 0.40 & 95.65 \\
\hline $70 \%$ NR-HNT & & 0.20 & 95.47 \\
\hline \multirow{3}{*}{$10 \%$ NR-HNT } & 2.96 & 1.29 & 93.06 \\
\hline & 11.8 & 4.21 & 97.08 \\
\hline & 17.0 & 5.13 & 92.88 \\
\hline
\end{tabular}

Table 2: Isotherm parameters for the removal of MB dye onto NR and NR-HNT.

\begin{tabular}{|c|c|c|c|c|}
\hline Isotherms & Parameters & NR & $\begin{array}{l}\text { NR-HNT } \\
(10 w t \%)\end{array}$ & $\begin{array}{c}\text { NR-HNT } \\
(50 \mathrm{wt} \%)\end{array}$ \\
\hline \multirow{4}{*}{ Langmuir } & $\left(\mathrm{mg} \mathrm{g}^{-1}\right)$ & 9.9502 & 6.6489 & -0.9061 \\
\hline & $\mathrm{K}_{\mathrm{L}}\left(1 \mathrm{mg}^{-1}\right)$ & 0.0222 & 3.9167 & -0.9958 \\
\hline & & 0.7260 & 0.0157 & -0.0694 \\
\hline & $\mathrm{R}^{2}$ & 0.8587 & 0.9720 & 0.9640 \\
\hline \multirow{3}{*}{ Freundlich } & $\mathrm{K}_{\mathrm{F}}\left(\mathrm{mg} \mathrm{g}^{-1}\left(1 \mathrm{mg}^{-1}\right)\right.$ & 0.2023 & 5.1603 & 2.6786 \\
\hline & $1 / \mathrm{n}$ & 0.8110 & 0.3330 & 1.6061 \\
\hline & $\mathrm{R}^{2}$ & 0.8873 & 0.8827 & 0.9761 \\
\hline \multirow{3}{*}{ Tempkin } & $\mathrm{A}\left(1 \mathrm{~g}^{-1}\right)$ & 5.4202 & 55.2580 & 4.7569 \\
\hline & $\mathrm{B}\left(\mathrm{J} \mathrm{mol}^{-1}\right)$ & 0.1340 & 1.2730 & 1.0150 \\
\hline & $\mathrm{R}^{2}$ & 0.9754 & 0.9287 & 0.9988 \\
\hline
\end{tabular}




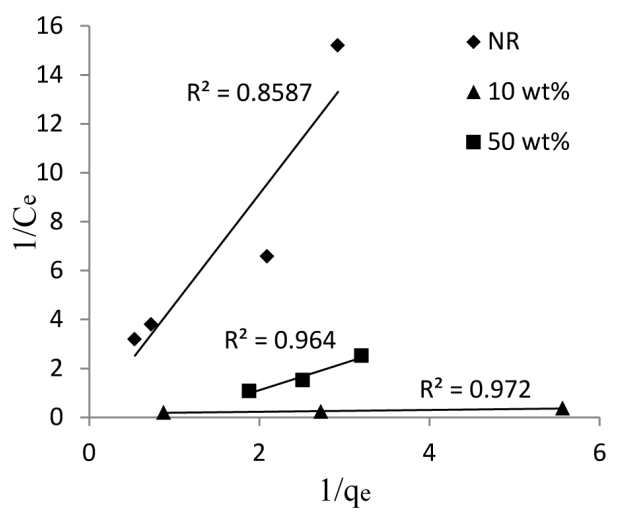

(a)

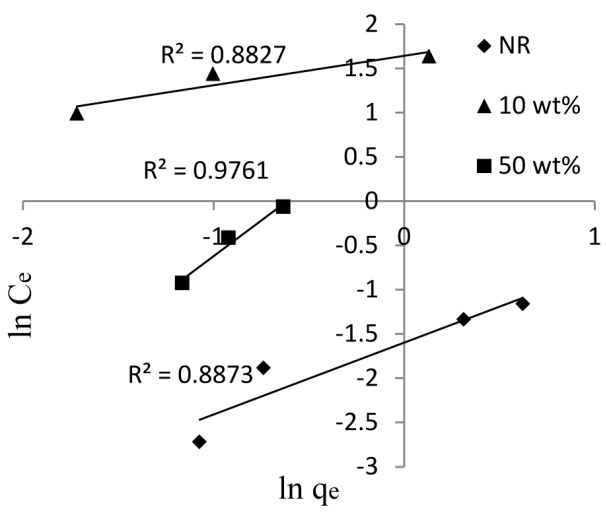

(b)

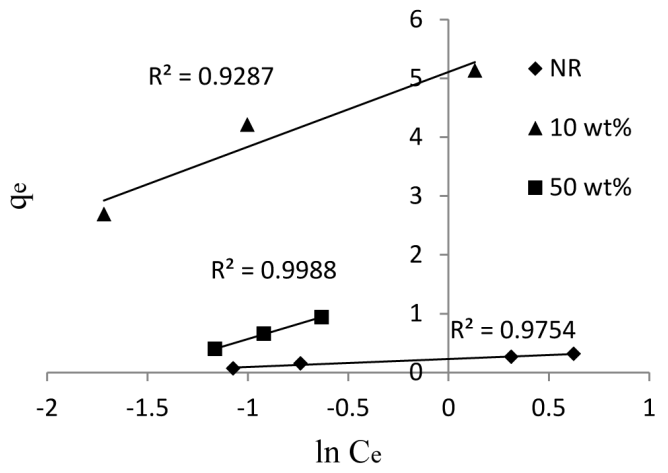

(c)

Figure 1: The (a) Langmuir, (b) Freundlich and (c) Tempkin adsorption isotherms for NR as well as $10 \mathrm{wt} \%$ and $50 \mathrm{wt} \%$ NR-HNT films.

Our findings show that the NR-HNT films exhibited superior adsorption properties in comparison to pristine NR films. Overall, the NR-HNT films exhibited a \%R of more than $80 \%$ irrespective of the HNT content, while pristine NR removed approximately $51 \%$ of $\mathrm{MB}$ within $500 \mathrm{~min}$. The enhanced adsorption of $\mathrm{MB}$ by the NR-HNT films can be attributed to the availability of HNT. Previous work reported that HNT is an excellent adsorbent for cationic dye. ${ }^{16}$ The surface of HNT is mostly negative at $\mathrm{pH} 2-12$. As the $\mathrm{pH}$ is increased, the surface of HNT becomes more negatively charged and thus, increasing the attraction between the negatively charged adsorbent and the positively charged cationic dye.

In this case, it can be seen that the $10 \mathrm{wt} \%$ NR-HNT has the highest $q_{e}$ among all the samples. The $q_{e}$ value decreased as the $\mathrm{wt} \%$ of HNT was increased. This is because the weight and adsorption sites of the adsorbent increased as the $\mathrm{wt} \%$ of 
HNT was increased but the amount of MB remained constant. A similar trend was seen in Peng et al.'s study. ${ }^{20}$

The influence of various initial MB concentrations was also studied. Values of $\mathrm{q}_{\mathrm{e}}$ and $\% \mathrm{R}$ are presented in Table 1 . It was found that $\mathrm{q}_{\mathrm{e}}$ increased from 1.29 to $5.13 \mathrm{mg} \mathrm{g}_{\mathrm{HNT}^{-1}}$ with the increase in initial concentration of MB from 2.96$17.0 \mathrm{mg}^{-1}$. These adsorption data were fitted to the Langmuir (a), Freundlich (b) and (c) isotherms as plotted in Figure 1. The coefficients are presented in Table 2.

It can be seen that the $10 \mathrm{wt} \%$ NR-HNT fitted the Langmuir isotherm (Figure 1(a)) indicating that the $\mathrm{MB}$ adsorbed as a monolayer on the surface of the film. In contrast, the $50 \mathrm{wt} \%$ NR-HNT gave a negative $\mathrm{q}_{\max }$ value. According to previous works, this shows that the Langmuir isotherm (Figure 1(a)) was insufficient in describing the adsorption of MB for the $50 \mathrm{wt} \%$ NR-HNT. ${ }^{21,22}$ Interestingly, similar to the NR film, the $50 \mathrm{wt} \%$ NR-HNT film best fitted the Tempkin isotherm (Figure 1(c)). Here, the difference in the adsorption phenomenon between the $10 \mathrm{wt} \%$ NR-HNT and $50 \mathrm{wt} \%$ NR-HNT may be attributed to the distribution of HNT in or on the NR film.

\subsubsection{NR-Ag composites}

Ag nanoparticles were also incorporated into the NR to form NR-Ag films. The films exhibited different shades of brown depending on the Ag content. This is indicative of the availability of various Ag particle sizes. The stabilisation of these Ag particles occurs via coordination with amine groups of protein which is naturally available in NR. ${ }^{23}$ Upon testing the films for the decolorisation of $\mathrm{MB}$, it was found that the NR-Ag films decolorised the dye via two mechanisms, adsorption and degradation. The NR functions to adsorb the MB dye while the Ag nanoparticles play a role in the degradation of the dyes.

The adsorption of MB on the NR was evidenced by the FTIR analysis. As shown in Figure 2(b), the peaks for $\mathrm{NR}$, attributed to $\mathrm{C}=\mathrm{C}, \mathrm{CH}_{2}$ and $\mathrm{CH}_{3}$ bending of natural rubber are positioned at 1657 and 833,1446 as well as $1374 \mathrm{~cm}^{-1}$ respectively. ${ }^{24}$ The $=\mathrm{NH}$ deformation and peptide linkage which originate from the protein in NR is proven by the peak at $3287 \mathrm{~cm}^{-1} \cdot{ }^{25}$ Another peak which is attributed to $=\mathrm{NH}$ coincides with the peak for $\mathrm{CH}_{2}$ at $1446 \mathrm{~cm}^{-1} \cdot{ }^{25}$ In addition, the peaks at 2961, 2925 and $2853 \mathrm{~cm}^{-1}$ of NR were attributed to asymmetry $-\mathrm{CH}_{3}$, asymmetry $-\mathrm{CH}_{2}-$ and symmetry $-\mathrm{CH}_{2}-$ and $-\mathrm{CH}_{3} \cdot{ }^{26}$ Additional strong peaks arise at 1603, 1392, 1335 and $887 \mathrm{~cm}^{-1}$ for the NR sample after adsorption with MB (Figure 2(c)) and these peaks match with MB (Figure 2(a)) which are at 1595, 1392, 1335 and $887 \mathrm{~cm}^{-1}$ respectively. ${ }^{27}$ This shows that NR can adsorb MB dye. 


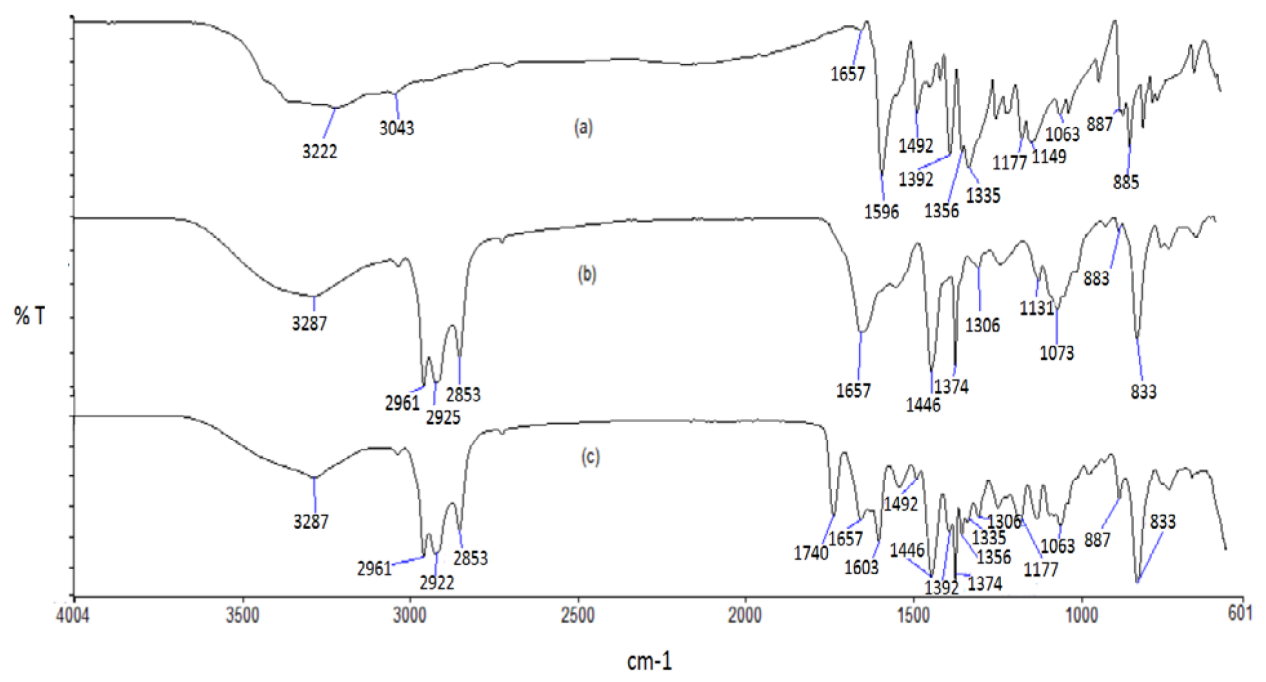

Figure 2: FTIR spectra of (a) methylene blue, (b) NR before adsorption, and (c) NR film after adsorption.

The effect of Ag content on the degradation of MB was investigated using a UVVis spectroscopy. As tabulated in Table 3, the percentage R of MB as well as the rate of degradation $(\mathrm{k})$ varied with the Ag content in the NR film. In this study, the total removal of $\mathrm{MB}$ achieved at least $90 \%$ in the presence of NR incorporated with $3-20 \times 10^{-4} \mathrm{wt} \%$ Ag. Furthermore, the percentage removal of MB increases within a shorter time, when higher quantities of Ag were applied. It is also found that the rate of degradation increases with the increase of Ag content in the film. For instance, the $\mathrm{k}$ value is $0.019,0.043,0.057,0.095$ and $0.131 \mathrm{~min}^{-1}$ for NR with $3 \times 10^{-4}, 7 \times 10^{-4}, 11 \times 10^{-4}, 18 \times 10^{-4}$ and $20 \times 10^{-4} \mathrm{wt} \% \mathrm{Ag}$ respectively. This trend can be attributed to higher number of active sites available for the reaction to occur when the Ag content was increased.

Table 3: Efficiency of percentage removal dependent on Ag content.

\begin{tabular}{ccc}
\hline Ag content $\left(\times 10^{-4} \mathrm{wt} \%\right)$ & Rate constant, $\mathrm{k}\left(\mathrm{min}^{-1}\right)$ & $\%$ Removal \\
\hline 3 & 0.019 & 91 \\
7 & 0.043 & 93 \\
11 & 0.057 & 92 \\
18 & 0.095 & 93 \\
20 & 0.131 & 95 \\
\hline
\end{tabular}




\subsection{Different Forms of NR Films}

The NR films were prepared in different forms to investigate the effect of different preparation methods on its surface morphology and indirectly its catalytic activity. The SEM images of the flatsheet and porous films are presented in Figure 3. As can be seen, latex casting resulted in films with a smooth surface while electrospinning gave rise to porous films. Hence the latter consists of a higher surface area. The films were then incorporated with Ag to understand how the surface morphology influences the degradation behaviour. Upon applying the films for the degradation of $\mathrm{MB}$, it was found that the time required to complete the degradation of $\mathrm{MB}$ were 92 and $30 \mathrm{~min}$ for the NR-Ag flatsheet and porous films respectively. This shows that the higher surface area of the porous film leads to an improvement in the catalytic performance. The kinetics of degradation was plotted according to the first-order reaction and the data were analysed. The $\mathrm{k}$ values as well as correlation coefficients $\left(\mathrm{R}^{2}\right)$ are presented in Figure 4. The k values for flatsheet and porous film are 0.022 and $0.141 \mathrm{~min}^{-1}$. This proves that the catalytic activity of the porous film is higher when compared to the flatsheet film. As can be seen from Figure 4, the degradation of MB by the flatsheet film initially occurs rapidly (the first $2 \mathrm{~min}$ ) and then occurs gradually. This can be related to the active sites which may partially be blocked by the MB molecule or its degradation products within the first few minutes. In contrast, degradation continuously occurred rapidly for the porous film. Although some active sites may partially be blocked by the MB molecule or its degradation products, however the higher number of active sites still available due to the higher porosity of the film may have resulted in the trend observed.
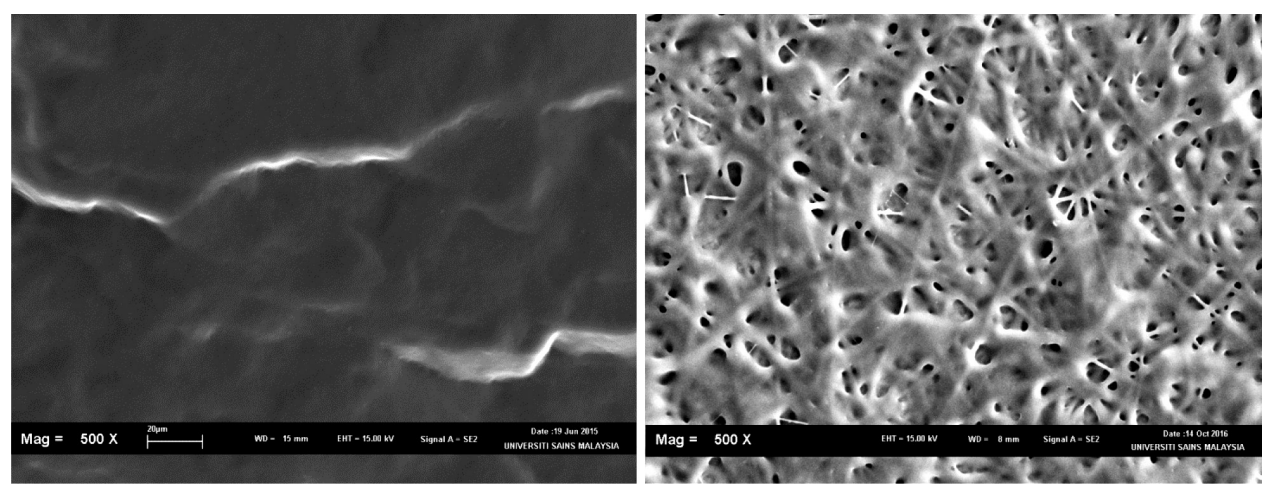

Figure 3: SEM images of NR flatsheet film (left) and NR porous film (right). 


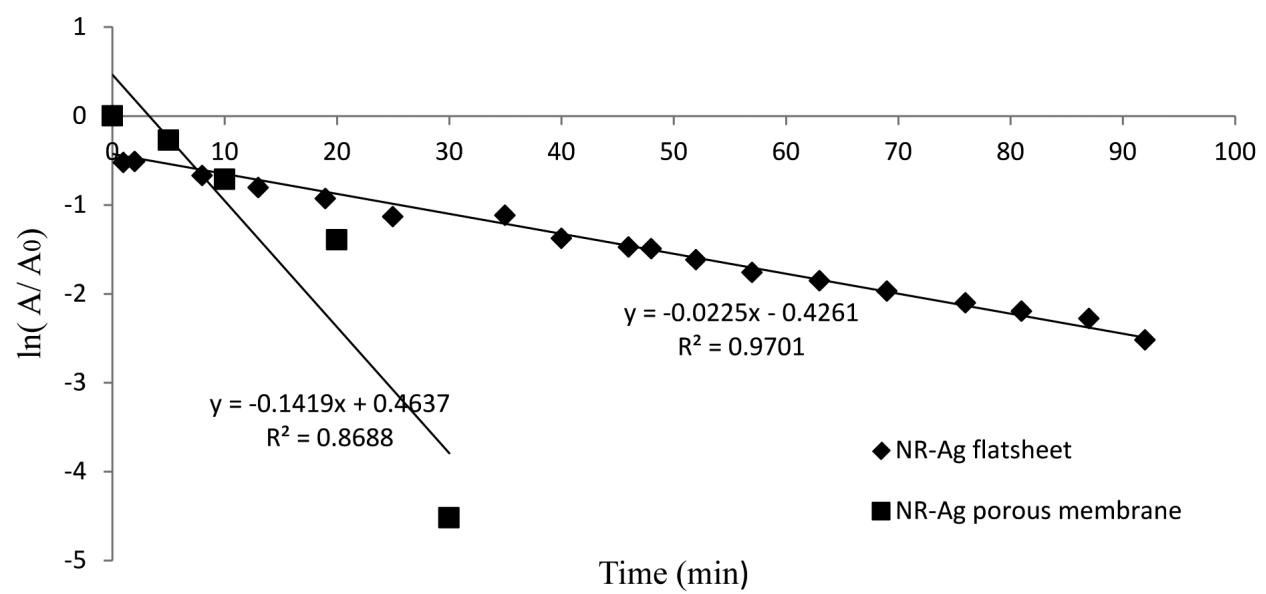

Figure 4: Kinetic of degradation for $(\bullet)$ NR-Ag flatsheet and $(\square)$ NR-Ag porous film.

\section{CONCLUSION}

In general, the capability of NR as an adsorbent or a catalytic film is influenced by several factors, mainly the type of filler incorporated into NR and the surface area of NR. Incorporation of adsorbing fillers such as HNT dramatically increases the adsorption properties of the resulting composite films. In contrast, incorporation of fillers such as Ag gives rise to catalytic properties to the films. However, the distribution of the filler on or in the NR as well as its amount largely influences these properties.

\section{ACKNOWLEDGEMENTS}

The authors would like to acknowledge the FRGS Grant 203/PKIMIA/6711419 for the financial support that funded this work as well as the Malaysian Rubber Board for supplying the natural rubber latex as a gift. The authors would also like to thank Prof. Dr. Sudesh Kumar from School of Biological Sciences, Universiti Sains Malaysia for providing the electrospinning machine.

\section{REFERENCES}

1. Dhananasekaran, S. Palanivel, R. \& Pappu, S. (2016). Adsorption of methylene blue, bromophenol blue, and coomassie brilliant blue by $\alpha$-chitin nanoparticles. J. Adv. Res., 7(1), 113-124, https://doi.org/10.1016/j.jare. 2015.03.003. 
2. Gao, J. J. et al. (2013). Adsorption of methylene blue onto activated carbon produced from tea (Camellia sinensis L.) seed shells: Kinetic, equilibrium, and thermodynamics studies. J. Zhejiang Univ-Sci. B Biomed. Biotechnol., 14(7), 650-658, https://doi.org/10.1631/jzus.b12a0225.

3. Iqbal, J. et al. (2011). Adsorption of acid yellow dye on flakes of chitosan prepared from fishery wastes. Arab. J. Chem., 4(4), 389-395, https://doi. org/10.1016/j.arabjc.2010.07.007.

4. Tehrani-Bagha, A. R. et al. (2011). The sorption of cationic dyes onto kaolin: Kinetic, isotherm and thermodynamic studies. Desalin., 266 (1-3), 274-280, https://doi.org/10.1016/j.desal.2010.08.036.

5. Gupta, V. K. et al. (2011). A comparative investigation on adsorption performances of mesoporous activated carbon prepared from waste rubber tire and activated carbon for a hazardous azo dye- Acid Blue 113. J. Hazard. Mater., 186(1), 891-901, https://doi.org/10.1016/j.jhazmat.2010.11.091.

6. Bhakya, S. et al. (2015). Catalytic degradation of organic dyes using synthesized silver nanoparticles: A green approach. J. Bioremed. Biodeg., 6(5), 1000312.

7. Sharma, K. et al. (2015). Silver nanoparticles: Facile synthesis and their catalytic application for the degradation of dyes. RSC Adv., 5(33), 2578125788, https://doi.org/10.1039/C5RA02909K.

8. Mehra, M. \& Sharma, T. R. (2012). Photo catalytic degradation of two commercial dyes in aquous phase using photo catalyst $\mathrm{TiO}_{2}$. Adv. Appl. Sci. Res., 3(2), 849-853.

9. Ullah, R. \& Dutta, J. (2008). Photocatalytic degradation of organic dyes with manganese-doped $\mathrm{ZnO}$ nanoparticles. J. Hazard. Mater., 156(1-3), 194-200, https://doi.org/10.1016/j.jhazmat.2007.12.033.

10. Tan, W. L., Abu Bakar, N. H. H. \& Abu Bakar, M. (2016). Natural rubber - inorganic composites: Beyond conventional application boundaries. In Hamilton, J. L. (Ed.). Natural rubber: Properties, behavior and applications. New York: Nova Science Publisher, 137-164.

11. Johns, J. \& Rao, V. (2011). Adsorption of methylene blue onto natural rubber/chitosan blends. Int. J. Polym. Mater., 60(10), 766-775, https://doi. org/10.1080/00914037.2010.551361.

12. Utara, S. \& Phatai, P. (2014). Adsorption characteristics of direct violet dye by natural rubber chips. Adv. Mater. Res., 844, 391-394, https://doi. org/10.4028/www.scientific.net/AMR.844.391.

13. Sriwong, C., Wongnawa, S. \& Patarapaiboolchai, O. (2012). Recyclable thin $\mathrm{TiO}_{2}$-embedded rubber sheet and dye degradation. Chem. Eng. J., 191, 210-217. 
14. Stropa, J. M. et al. (2016). Use of natural rubber membranes as support for powder $\mathrm{TiO}_{2}$ and $\mathrm{Ag} / \mathrm{TiO}_{2}$ photocatalysis. J. Braz. Chem. Soc., 27(3), 575583.

15. Sriwong, C. \& Tejangkura, W. (2015). AC/TiO $/ 2$ rubber composite sheet catalysts; fabrication, characterization and photocatalytic activities. Advanced Materials and properties. Paper presented at MATEC Web of Conferences 30, 01006. Retrieved 4 November 2015 from http://www. matec-conferences.org/articles/matecconf/abs/2015/11/matecconf_ icmset2015_01006/matecconf_icmset2015_01006.html.

16. Zhao, M. \& Liu, P. (2008). Adsorption behavior of methylene blue on halloysite nanotubes. Microp. Meso. Mater., 112(1-3), 419-424, https://doi. org/10.1016/j.micromeso.2007.10.018.

17. Bulut, Y. \& Aydin, H. (2006). A kinetics and thermodynamics study of methylene blue adsorption on wheat shells. Desalin., 194(1-3), 259-267, https://doi.org/10.1016/j.desal.2005.10.032.

18. Rao, M. N. et al. (2011). Adsorption studies of methylene blue dye using prepared low-cost activated Kaza's carbons. J. Chem. Pharm. Res., 3(5), 363-375.

19. Derakhshan, Z. Baghapour, M. A. \& Ranjbar, M. (2013). Adsorption of methylene blue dye from aqueous solutions by modified pumice stone: Kinetics and equilibrium studies. Int. Q. J., 2(3), 136-144, https://doi.org/ 10.17795/jhealthscope-12492.

20. Peng, Q. et al. (2015). Adsorption of dyes in aqueous solutions by chitosanhalloysite nanotubes composite hydrogel beads. Microp. Meso. Mater., 201, 190-201, https://doi.org/10.1016/j.micromeso.2014.09.003.

21. Basibayuk, M. et al. (2007). Investigation of a basic dye adsorption characteristics of a non-living submerged aquatic plant (Myriophyllumspicatum). Asian J. Chem., 19(3), 1693-1702.

22. Robinson, T. Chandran, B. \& Nigam, P. (2002). Removal of dyes from a synthetic textile dye effluent by biosorption on apple pomace and wheat straw. Water Res., 36, 2824-2830, https://doi.org/10.1016/S0043-1354(01)005218.

23. Abu Bakar, N. H. H., Ismail, J. \& Abu Bakar, M. (2007). Synthesis and characterization of silver nanoparticles in natural rubber. Mater. Chem. Phys., 104, 276-283, https://doi.org/10.1016/j.matchemphys.2007.03.015.

24. Phetphaisit, C. W., Yuanyang, S. \& Chaiyasith, W. C. (2016). Polyacrylamido2-methyl-1-propane sulfonic-acid-grafted-natural rubber as bio-adsorbent for heavy metal removal from aqueous standard solution and industrial wastewater. J. Hazard. Mater., 301, 163-171, https://doi.org/10.1016/j. jhazmat.2015.08.056. 
25. Li, C. et al. (2012). Ammonium-assisted green fabrication of graphene/ natural rubber latex composite. J. Polym. Comp., 34(1), 88-95, https://doi. org/10.1002/pc.22380.

26. Rolere, S. et al. (2015). Investigating natural rubber composition with Fourier transform infrared (FT-IR) spectroscopy: A rapid and non-destructive method to determine both protein and lipid contents simultaneously. Polym. Test, 43, 83-93, https://doi.org/10.1016/j. polymertesting.2015.02.011.

27. Olivella, M. et al. (2012). A mechanistic approach to methylene blue sorption on two vegetable waste: Cork bark and grape stalks. Bioresour.,7(3), 33403354 . 